\title{
可動的構法の体系的整理に関する研究 RESEARCH ON SYSTEMATIZATION OF THE MOVABLE BUILDING CONSTRUCTIONS
}

\author{
真 鍋 恒 博*, 西山明 彦**, 佐久間 巧*** \\ Tsunehiro MANABE, Akihiko NISHIYAMA and Takumi SAKUMA
}

\begin{abstract}
There exist many ideas and real cases of movable building constructions in these days. For example, movable domed roof, movable partition and so on. These movable building constructions aim at corresponding to the change of demand for buildings. But there are only a few studies on movable building constructions in the general. In this study, we apply the theory on building construction system, which we have been studying, to movable building constructions. We analyzed from several viewpoints and classified movable building constructions systematically.
\end{abstract}

Keywords : mobility, systematization, demand, level of building system 可動性，体系化，要求，構法レベル

\section{1. 研究の背景・目的}

建築は大地に固定されているすの、と一般には考えら れているが、以前から様々な可動建築の実例やアイディ アが見られる。また、技術の発展にともなって、開閉式 ドームのような大規模な可動構造物も実現されるように なってきている。これらの可動的構法は、いずれも建築 に対する要求の変化あるいは複数の要求に、建物の属性 を変化させることで対応しているすのであると考えられ る。構法計画学における要求と構法の関係の解明という 立場からは、これらの全体像を明らかにしておく必要が ある”。しかし、個々の手法に関する研究開発はなされ てきているむのの、対象の全体像を広くとらえた総論的 な研究は未だ数少ない2)。

そこで本研究は、可動的構法を要求と構法レベル8)の $2 つ$ 観点から体系的に整理し、その全体像を把握する ことを目的とする゙。

\section{2. 研究の対象}

開口部、開閉式屋根、可動間仕切等の部位レベルの可 動的構法を主たる対象とするが、それ以外の家具や機械 装置、さらに乗り物や遊具、橋梁等の土木構筑物む人間 等をとりまく空間を構成するむのとして、「可野性」とい う共通点に着目し、原理を対応させることにより同様に 扱う。また「可動性」を広く解釈し、機構的なるす的動き 以外にも、光・音など情報の動き(変化) む対象とした。

\section{3. 建築における可動性の定䉝}

\section{1 可動性の目的}

建築においては様々なスケールやサイクルでの時間的 変化が見られる。本研究ではこれらの建築の時間的変化 の内で、人間が意図して関わりあっているもののことを 特に「建築における可動性」と定義し、以後「可動性」

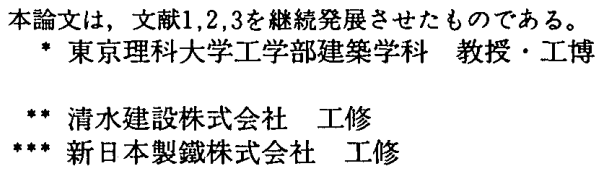

Prof., Dept. of Architecture, Faculty of Engineering, Science Univ. of Tokyo, Dr. Eng.

Shimizu Corporation, M. Eng.

Nippon Steel Corporation, M. Eng. 
という表現をした場合には、常に意図的にそれを利用す る人間の存在を前提とした時間的変化を指するのとする。

そしてこの様な可動性を構法に持たせる目的には以下 の 2 通りが考えられる。

(1)建物に対する要求は構法が動くことを前提としないが、 要求と構法との間に何らかの「ずれ」が生じたため、構法 を動かすことによってそれに対応し、動いた結果を目的 とする場合 (結果目的型)

(2)建物に対する要求が構法が動くことを前提とし、構法 (空間) が動いている最中の過程を目的とする場合（過 程目的型)

この様に構法の可動性は、その本質的な目的がどこに あるかに着目すれば、「結果目的型」と「過程目的型」の 2 種頻に大別できる（図一1）。また実際にはこれら2つ の目的に対応するむのむある(e.g. 乗り物による移動)。

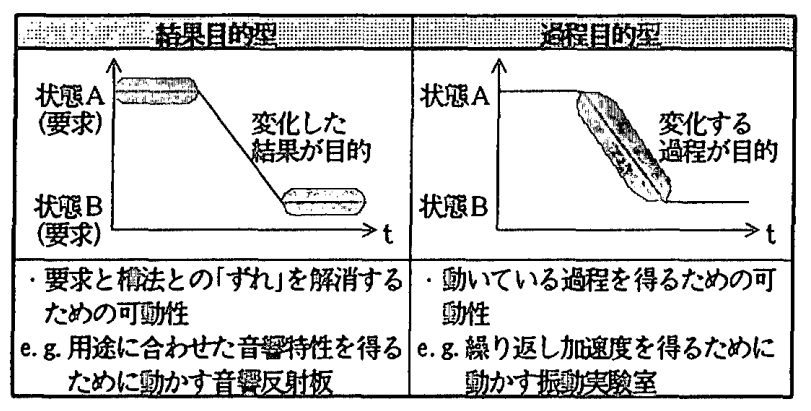

図-1 結果目的型/過程目的型

\section{2 結果目的型の可動的棓法}

1) 要求と構法の[ずれ]

構法は、本来人間の要求に合せて造られるものである が、何らかの原因により構法が要求を満たさなくなった 場合、要求と構法の間に「ずれ」が生ずる。その原因には、 要求は一定であるが建築が劣化等により要求を满たさな くなる場合と、構法は一定であるが要求が変化するか複
数あるために構法が要求を満たさなくなる場合とがある。 この内、要求が 2 通りに变化する場合す、要求の種類と いう観点から見れば、複数の要求とみなすことができる。 以上の観点から、要求と構法の「ずれ」を生ずるパターン は図ー2のように分類することができる。

\section{2)「ずれ」に対する構法の対策原理}

このような「ずれに対しては、構法の側を要求に合せ る必要がある。以下にその方法の原理(対策原理)を示す。

構法变化型（図－2中(1)）に対する構法の対策原理 ${ }^{5}$ ) には、予め対応、付加・除去、交換、自体変化の $4 \supset か ゙$ 考えられる（表－1）。このうち付加・除去、交換に関 しては「互換性のある構法」によって対応することが可 能であり、これは可動的な構法につながる。本研究では 以下複数の要求（図一2中(2) (7) を主として対象とす るが、上記のような場合についても同様の考え方で手法 を分類することが可能である。

\section{表- 1 構法变化型に対する対策原理}

\begin{tabular}{|c|c|}
\hline 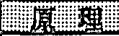 & 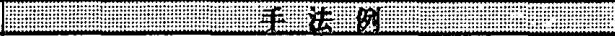 \\
\hline Fめ対店 & 兔霰權造、不同迌下防止のための建物のジャッキアップ \\
\hline 付加·除去 & ペンキの症り直し、污れを拭き取る \\
\hline 交換 & サッシの交換、ボルトの交換 \\
\hline 自体变化 & 中住化したコンクリートヘのアルカリ付与 \\
\hline
\end{tabular}

複数の要求に対応する方法の原理は、図一3のように 整理することができる。本研究では図一 3 中の斜線部分 に位置付けられる可動的構法が対象となる。

なお 3 種類以上の要求が起こる場合す、2 種類の場合 の組合せとして扱うことができる。また要求の変化が繰 り返される場合には、1 回の変化のみに着目することに より同様に組合せとして扱うことができる。これらの様 々なヴァリェーションについては、煩瑣をさけるためこ こでは省略する。

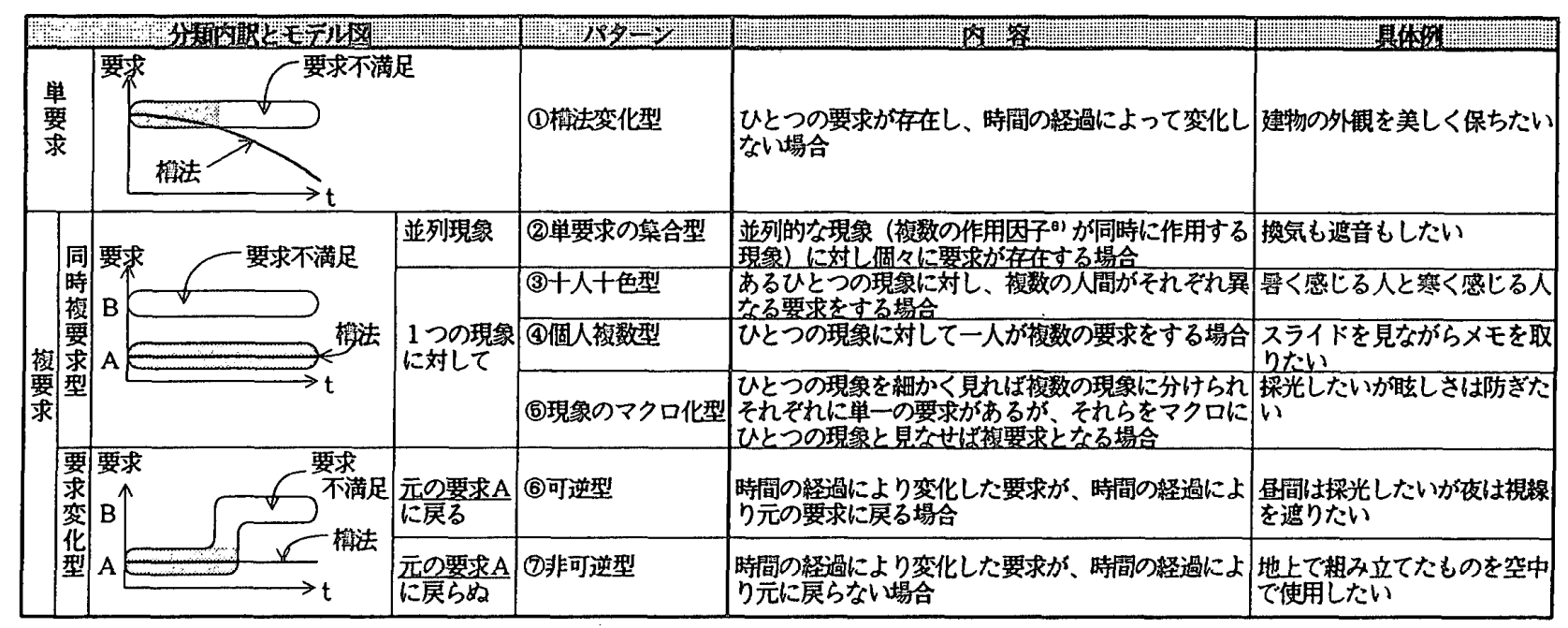

図一２要求と構法の「ずれ」のパターン 


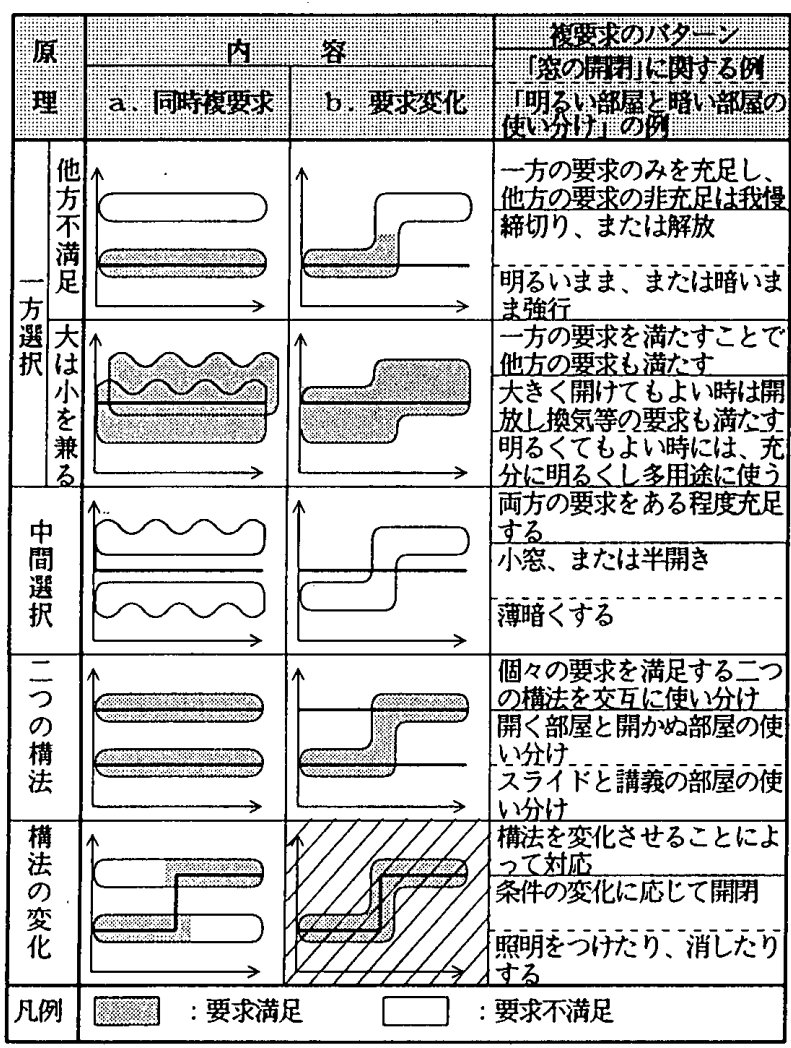

図一 3 複要求の対応の原理

\section{3 過程目的型の可動的構法}

動作が連続してる間のみ要求が満たされ、動作前後の 状態に対する要求は存在しない。

過程目的型には、速度(運動)を維持することを目的と する場合と、加速度を維持あるいは変化させることを目 的とする場合の 2 通りがある。前者は主に周囲との相対 的な位置の移動によって環境の連続的な変化を得るすの であり (e. g. 観覽車)、後者は力を加えることにより環境 を変化させるものである(e.g. フライトシミュレータ)。

\section{4. 各種観点による可動的構法の分類}

4. 1 ライフサイクル段階

建物のライフサイクルは、採取・製造・建設・供用・ 維持保全・解体・回収再生・廃萧処理の 10 の段階に分 けることができる”。そのうち供用・維持保全について は実際に建物を使用むしくは維持している段階であり、 その他については建物の施工に関連する段階であるとい える。建築の構法に可動性が必要とされる要求は、この ような時系列段階に着目すれば、使用・維持段階と施工 段階とに大別することができる（図一4）。

\section{2 内的要因 - 外的要因}

建物に対する要求の変化には、自然環境や騒音等の外 的要因によるるのと、それらとは無関係な内的要因によ
るものとがある。構法に可動性が必要とされる要求は、 要求の「ずれ」の原因がどこにあるのかに着目すれば、内 的要因と外的要因の 2 種類に大別することができる（図 $-5)$ 。

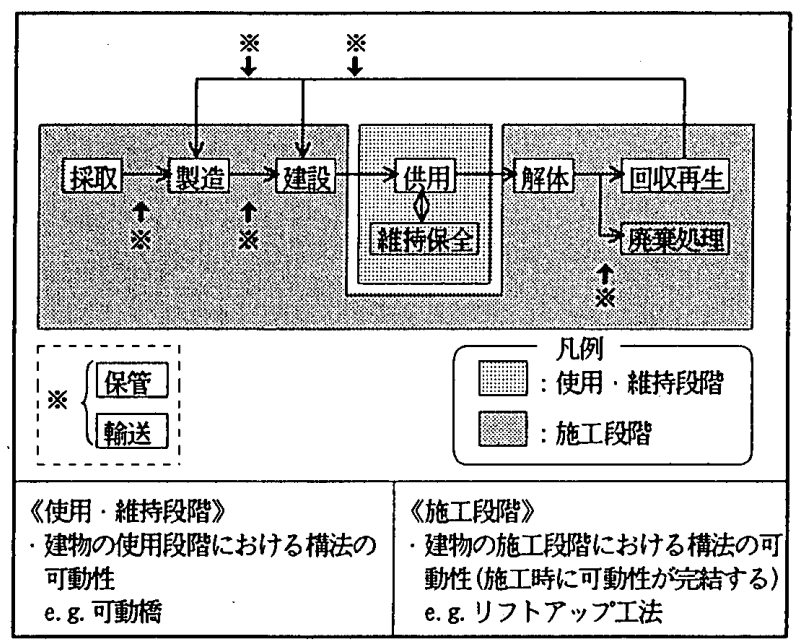

図一 4 使用・維持段階/施工段階

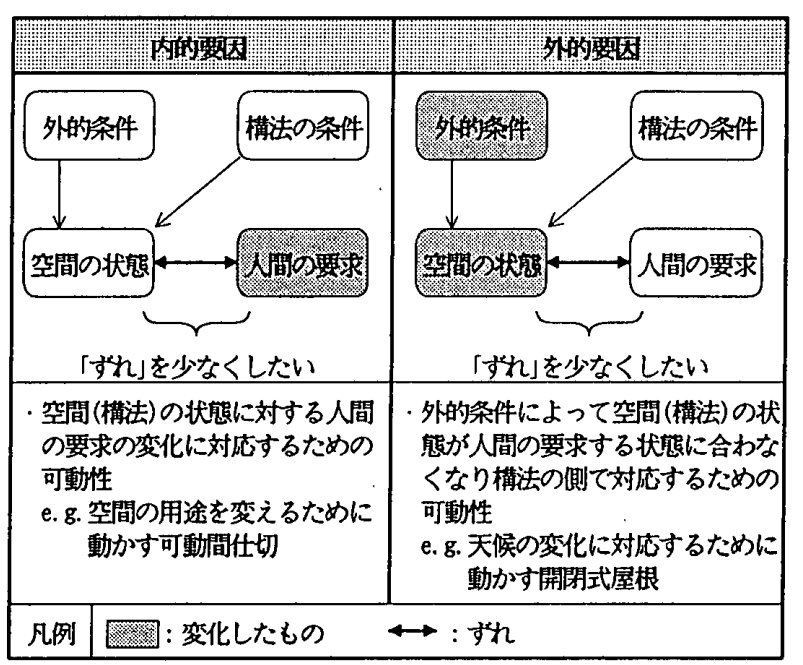

图 -5 内的要因 $/$ 外的要因

また要求の種類を単純化して考えれば、内的要因に対 しては主として「变えたい」、外的要因に対しては主と して「保ちたい」という要求に帰着する。ただしこれら は着目する構法レベルによって異なり、例えば外的要因 に対して、部屋の中の明るさや気温等の環境条件を「室 空間レベル」で見た場合には要求は変化の抑制であり、 日除けや断熱戸の操作で光や熱の制御性能を変化させる という「部位レベル」で見た場合には変化の促進が要求 となる。

以上の 2 つの分類観点と、結果目的 - 過程目的の分類 を組合せることによって、可動性を必要とする要求は 8 つのパターンに分類することができる（表ー2）。 
表ー 2 要求の 8 湢類のパターン

\begin{tabular}{|c|c|c|c|c|}
\hline & 慗 & 分賏 & 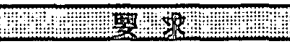 & 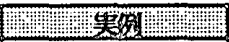 \\
\hline 結 & 使用維持 & 内的要因 & 部屋の用途を変えたい & 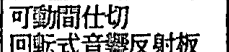 \\
\hline 自 & & 外的要因 & $\begin{array}{l}\text { 天候の受化に対し室内の現 } \\
\text { 境保たん }\end{array}$ & 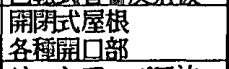 \\
\hline 型 & 施工 & 内的要因 & 作啬場所を変えたい & $\begin{array}{l}\text { リフトアップエ法 } \\
\text { パソタ.Kーム公洁 }\end{array}$ \\
\hline & & 外的要因 & 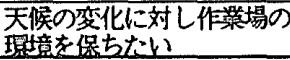 & 可垫式屋内作䃯場 \\
\hline 過 & 使用維持 & 内的要因 & 影の変化を楽しみたい & 宇宙旅行体駼施設 \\
\hline & & 外的要因 & 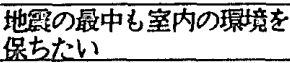 & 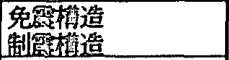 \\
\hline 型 & 施工 & 内的要因 & 作荟中の環境を変えた & 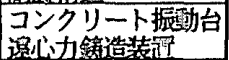 \\
\hline & & 施婹因 & 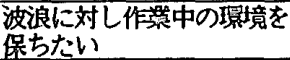 & 水上作㯃台 \\
\hline
\end{tabular}

\section{3 勛作の貝体的な目的}

\section{1) 結果目的型}

可動部分で複数の状態を持たせることの具体的な目的 は、空間" の用途や着目する構法レベルによって異なっ てくるが、実例に即してそれらをすべて総合すると以下 の様に分類できる昂。

(1)対象物の属性の変化への追随

空間内に存在する人間や物の状態の変化に対応して、 それらの環境状態を保つための可動性と、空間内に存在 する人間や物の環境を、外部環境の変化から影響を受け ないようにするための可動性がある。どちらす人間や物 を取り巻く環境状態を維持することが目的である。 (2)用途の変化への対応

(1)とは逆に、空間内に存在する人間や物の環境状態を 積極的に変えることが目的である。環境状態を変えるの ではなく、対象となるすの自体の存在を無くすというこ とす考えられるが、これは着目する構法レベルにす関連 し、上位のレベルの瑔境状態を変えるために下位のレベ ルの存在を無くすという場合であると考えられる。

(3)運搬・移動・位置変化

空間自体を移動する場合と、空間内に存在する人間や 物の移動が目的の場合がある。空間自体の移動に関して は、使用・維持段階では、移動の前後両方において機能 を発揮しているのに対し、施工段階において移動前は本 来の機能を果たしていない。

(4)空間の保持

空間そのものを維持するために破壊や少化を防ぐ、あ るいは修正するための可動性である。(1)空間の環境状 態に着目しているのに対し、これは空間そのあのの維持 に着目している。

以上をまとめると表ー3のようになる。

\section{2) 過程目的型}

運動によって、人間や物を含んだ空間全体の罾境状態 を変化させる場合と、単に視覚としての罢境の変化（情 報の変化）がある。
表-3 結果目的型の具体的目的

\begin{tabular}{|c|c|c|}
\hline & & \\
\hline 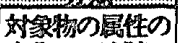 & 対皱U・物)の虽性 & -姿势や体位の变化に対応して寸 \\
\hline 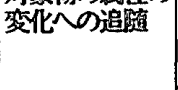 & の変化への迫随 & 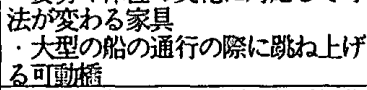 \\
\hline & 外的采件の変化への & 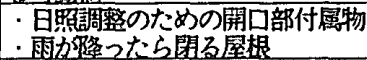 \\
\hline 用途の変化への & 苚途目的変化に対応 & - 窒用途に応してプランや装飾等 \\
\hline & した空間の匴競条件 & を変える \\
\hline & 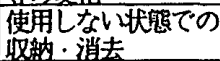 & 化收内队通股時の折り是み、小型 \\
\hline 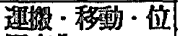 & 被数の位置での使用 & 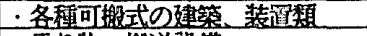 \\
\hline 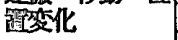 & 坟象物 & 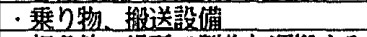 \\
\hline & 俳禁性の確保 & 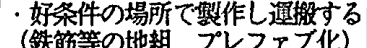 \\
\hline 㔖間の保持 & $\begin{array}{l}\text { 力学的に有利な状艵 } \\
\text { 保持 }\end{array}$ & 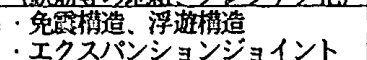 \\
\hline & 劣化など0 & ·劣化に詨子る補修交換 \\
\hline
\end{tabular}

\section{(1)運動自体が目的}

常に力を加え、加速度を与えることで空間のエネルギ 一状態を変化させる場合と、エネルギー状態の変化が目 的ではなく、周囲との相対的運動による環境状態の変化 （位置や方向の連続的な変化）が目的の場合がある。 (2)情報の変化

人間の注意を引きつけ、効果的に情報を伝達するため に、情報自体を常に変化させる方法がある。これは着目 する時間のサイクルによっては結果目的型とる捉えるこ とが出来る ${ }^{10)}$ 。また動き自体の中に情報性はないが、 単に対象の状態が刻々と变化していくこと自体が面白い という場合がある。

以上をまとめるとの表一 4 のようになる。

\section{表-4 過程目的型の具体的目的}

\begin{tabular}{|c|c|c|}
\hline \multirow{2}{*}{ 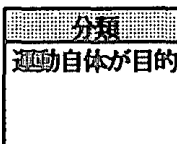 } & 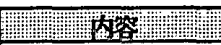 & 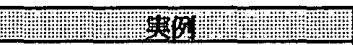 \\
\hline & $\begin{array}{l}\text { 提㢦等の加通度を与 } \\
\text { える }\end{array}$ & 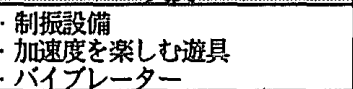 \\
\hline 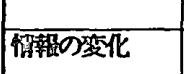 & 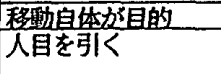 & 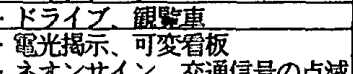 \\
\hline & 哩气自体力゙目的 & 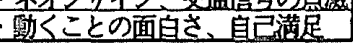 \\
\hline
\end{tabular}

\section{5. 手法の体系的整理}

本研究では可動的構法の実例を、建築関連雑誌(18誌、 12 年分)。単行本(18冊) ・カタログ(34社、130件)等から

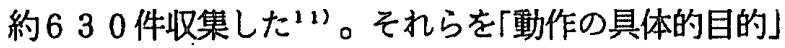
と「構法のレベル」の 2 曺によるマトリクスによって体系 的に整理し、その全体像を把握した（表一5。表一6）。 ただし一つの手法について、着目する観点によっては複 数の分類に当てはまるあのあある。さらに収集した実例 になかったものでも、演繹的に抽出できるような手法に ついては加えた。

ここではこれらの 2 軸を取り上げたが、本研究で分析 した他の様々な分穎観点による体系的整理が可能である。 
表一 5 手法の体系的整理(1)

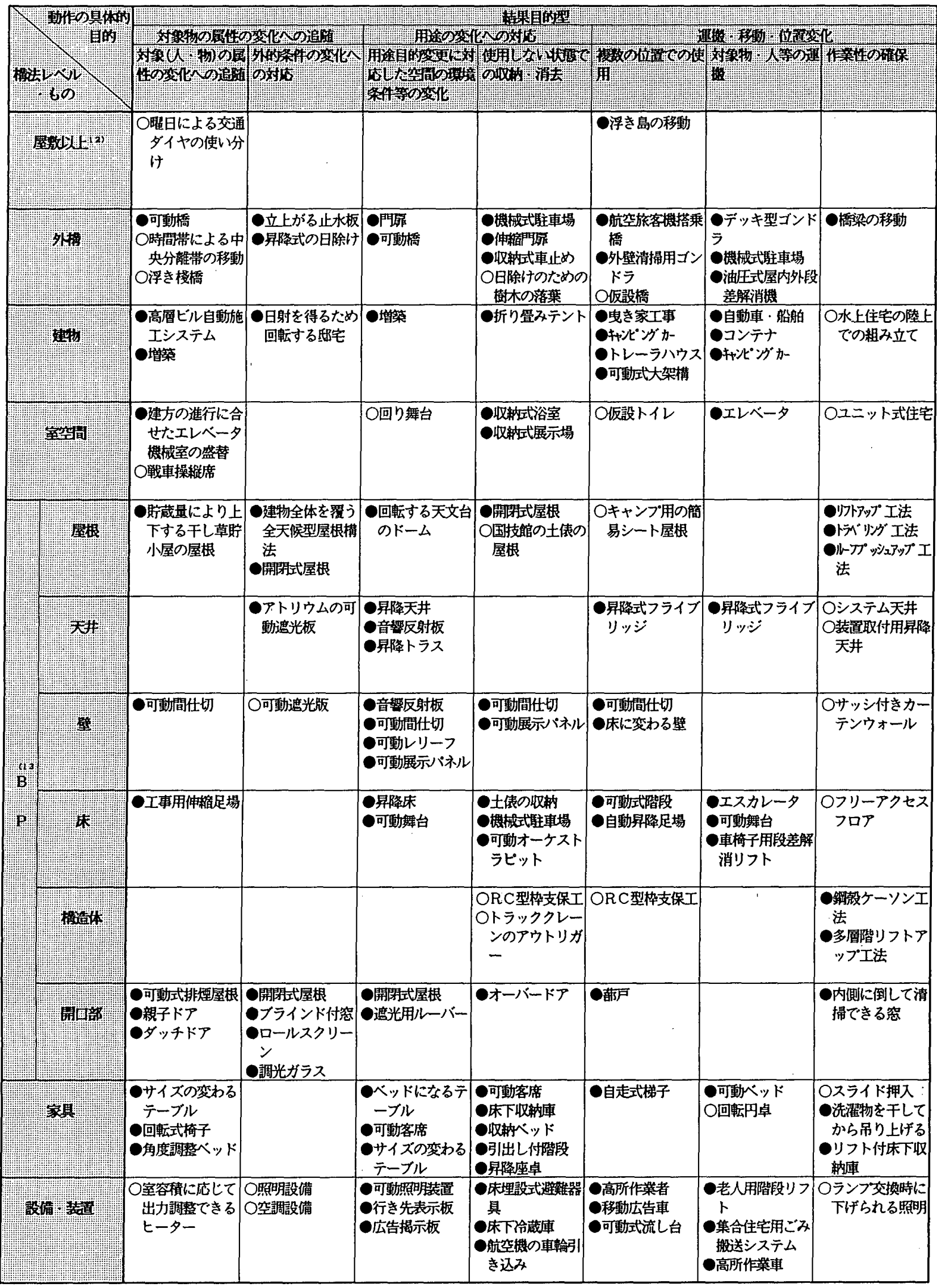

凡例 ○: 今回収集した実例にあったもの $O$ ：收集した实列にはないがあり得るもの 
表一 6 手法の体系的整理 (2)

\begin{tabular}{|c|c|c|c|c|c|c|}
\hline 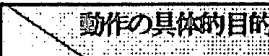 & 的洫自 & 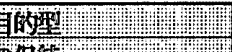 & 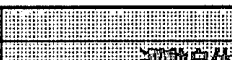 & 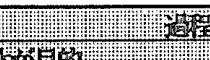 & 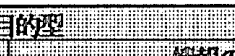 & 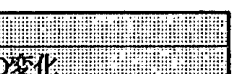 \\
\hline as & 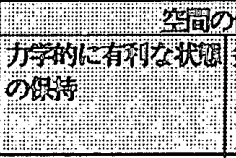 & 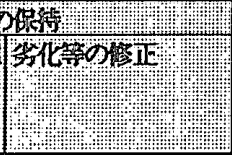 & 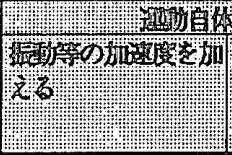 & 程 & (1) & W \\
\hline 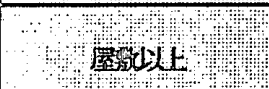 & 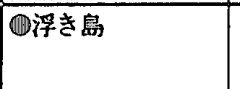 & & \begin{tabular}{|c|} 
O回転して重力を得 \\
る穻宙都市
\end{tabular} & & & \\
\hline \$1 75 & O列車止めダンパー & & & & (1)点裁式交通酶識 & $\begin{array}{l}\text { O回転するモニュメ } \\
\text { ント }\end{array}$ \\
\hline $\begin{array}{ll}4+4 \\
4\end{array}$ & 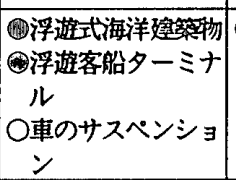 & $\begin{array}{l}\text { O不同沈下修正シス } \\
\text { テム }\end{array}$ & $\begin{array}{l}\text { 回鉣して重力を得 } \\
\text { る宇宙船 } \\
\text { ○ジェットコースタタ }\end{array}$ & 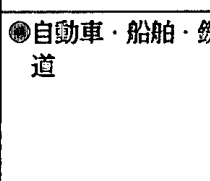 & $\begin{array}{l}\text { O街頭宣伝車 } \\
\text { Oレ一ス観浅 }\end{array}$ & 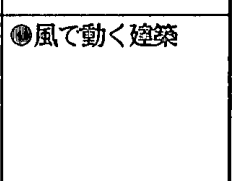 \\
\hline 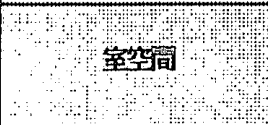 & & $\begin{array}{l}\text { 佼換可能なユニッ } \\
\text { 卜 }\end{array}$ & 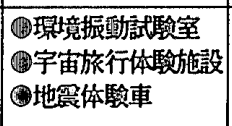 & $\begin{array}{l}\text { 田大観臨車 } \\
\text { 回输展望室 }\end{array}$ & & \begin{tabular}{|c|} 
○外からシャフトトの \\
見えるエレベータ
\end{tabular} \\
\hline & \begin{tabular}{|c|} 
Oモルタル仕上げ屋 \\
上の目地
\end{tabular} & & 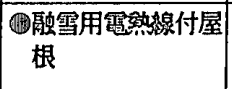 & & & $\begin{array}{l}\text {-10回転する屋根 } \\
\text {-10開開屋根 }\end{array}$ \\
\hline \#) & ○吊り天井 & & & & & $\begin{array}{c}\text { ○お化け屋影の下が } \\
\text { ってくる天井 }\end{array}$ \\
\hline & 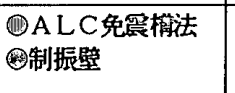 & & & & & \\
\hline 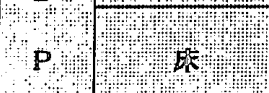 & $\begin{array}{l}\text { ○コンピュータル } \\
\text { ムの免露床 }\end{array}$ & ○タイルカーペット & 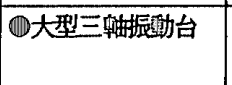 & & 四昇降舞台 & \\
\hline 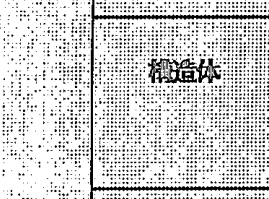 & 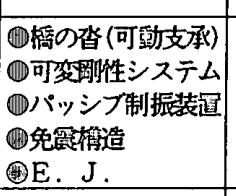 & & 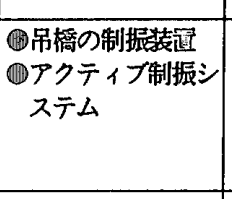 & & & \\
\hline 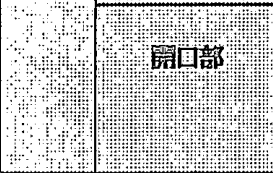 & & & & & & O開開式屋根 \\
\hline 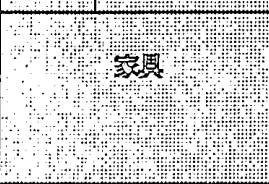 & & 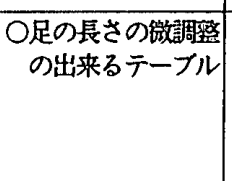 & O本馬 & & O伝言板 & $\begin{array}{l}\text { O動くインテリア: } \\
\text { オフジェ }\end{array}$ \\
\hline 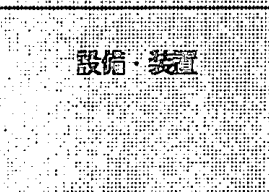 & $\begin{array}{l}\text { Oタクトの伸縮ジョ } \\
\text { イント }\end{array}$ & 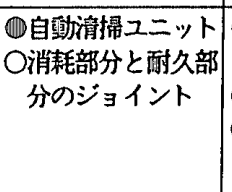 & 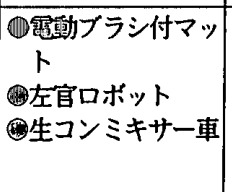 & & 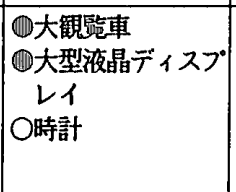 & ○からくり時計 \\
\hline
\end{tabular}

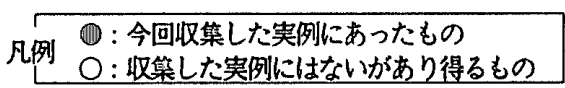




\section{6. まとめ}

以上のように可動的な構法の全体像を把握することが できた。さらに収集した手法を可動性の目的と構法レべ ルの 2 つの分類軸にあてはめた結果、収集したすべての 実例をいずれかの分類項目に対応づけることができ、こ の分類軸が可動的構法を整理する上では妥当であること が分かった。収集分類した実例の分布を見ると、構法レ ベル別では「屋敷以上」レベル（巨大なスケールのもの） を除く之極端な偏りは見られなかった。また目的別では、 「用途の变化への対応」が多いことが分かった ${ }^{14)} 。$

今後は個々の可動性について、動力源と伝達機構や可 動支承部分のディテール等、可動性を実現するための具 体的な構法等に関する分析を行なう必要がある。

なお本研究を進めるにあたっては、田島英治君、西村 博基君、馬越雅治君、山田仁君らの努力によるところが 大であった。

注

1)「全体像を明らかにする」こと自体か研究の目的として重要であるこ とに関しては文献 $4 ， 5$ を参照

2）可動的櫣法を扱ったものには文献6，7，8がある。

3）文献9中の「手法のレベル」、文献 10 中の「4-1. 構法原理の抽出」、

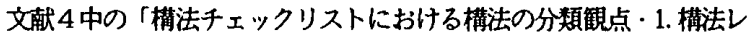
デ, 㐱照

4)このような定性的・原理的公分類体系の追求は、一般の定最的デー夕 の裹付けを前提とした調査・央駶研究とス夕イルを異にするため、研 究としての洒值を哂好ないとする向きもある。しかし構法計画纪関す る一連の理論研究（文献1 1，12，13，14）は、い执已本研 究と同様の覞点から行われており、すでにこの種の研究論文のスタイ 儿認知されていると考えられる。

なお、本論文の内容の一部は、投稿倿の查読期間があまりに長かっ

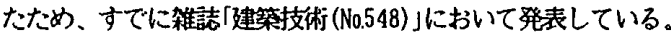

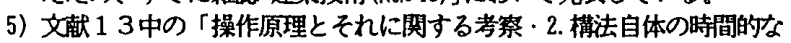
変化させ方の原理」侵照

6) 文献 11 中の「1-3. 用語の定艇」参照

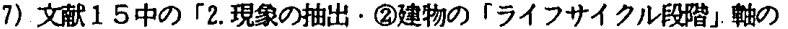
設定」萶照

8こここでの空間とはは周曲を部位等て曲まれた架間だけでなく、荷台等の 特定の部位等に付随する空間も含む。

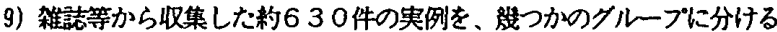
ことによって㯕能的に分類したものであるため、必ずしもシステマテ イックではないが、䒠用的なレベルでは粍羅していると考えられる。

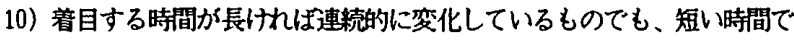

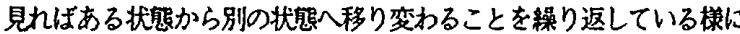

捉えることが出来る。

11) 収集したデータは構法レベル、要求、建物種、空間種等の18種類の 分類筧点による検索が可能となるようにデータベース化した。また、 本論文発表後も手法例の充実を継綍している。

12）敷地全体(敷地と建物を含む)をここでは屋䑤と定義する。構法レベル を区分するスケールはあくまて相対的なものであるため、ここでは最 上位のレベルを[屋敖以上」とし、これには屋影だけでなく、都市や集 落等の样々なレベルを含ませている。また建㭉以外の対象についても 同棣に対庥させることが出来る。

13） Building Partition の略で、詳細は文献16を营照

14）あくまでも本研究において収集した実例における分布であるため、世 の中にある全ての手法の分布とは必ずしも一致するとは言えないが、 参考までに示した。

\section{参考文献}

1) 真鍋佰博，田島英治，馬越雅治，佐久間巧：要求と動き方による可動 的構法の分析一新. 可動建筑論（その1）-（日本建学学会大会学術 講演梗摡集 1993)

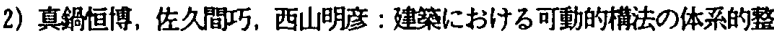
理一新・可動建論（その2) - (日本建学会大会学街講演梗摡集 1993)

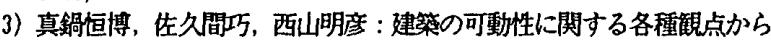
の分析一新·可動建筑論（その3）-（日本建築学会大会学術講演梗 概集 1993)

4）真鍋桓博。平林勇一，林 理：搆法チェックリストの提案（日本建榮 学会大会学術瀞演梗概集 1981)

5）真鍋恒博：建筑構法計画学（建築技術 N0.524），株式会社建築技術， pp. $238 \sim 245,1994.1$

6）真鍋佰博：可動建築論，井上書院，1971

7) W. Zuk, R. H. Clark: Kinetic Architecture, Reinhold, 1970

8）真鎿佰博：建築の可動性とそれに対応する構法に関する研究（学位論 文 東京大学 1974)

9）真鉿佰博，平林勇一：作用因子制御手法に関する基整的研究（日本建 築学会大会学術講演梗概集 1978)

10）真鎿佰博，天野友義 : 要求に対応する棤法原理の抽出及び体系化の方 法 (日本建宛学会大会学術講演梗概集 1982)

11）真鎿佰博，平林勇一：「水」と建筑との間に生ずる現象とその制御手 法の体系化に関する研究一その 1 「水」と建榮との間に生ずる現象の 体系化一（日本建学会論文報告集 1981.9)

12）真鍋佰博，平林勇一：「水」と建筑との間に生ずる現象とその制御手 法の体系化に関する研究一その2「水」と建筑との間に生ずる現缘の 制御手法の体系化一（日本建築学会論文報告集 1982.9)

13）真船佰博，中村佼彦 : 現象の制御手法に於计る「操作原理」に関寸る 考察（日本建築学会大会学術講演梗概集 1986)

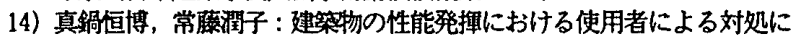
関する研究一構法計画学におけ施建等の使用者の役割（その1）（日本建学会計画系論女報告集 1990.10 )

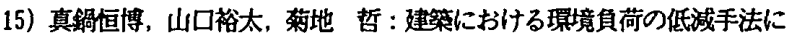
関守る研究（日本建筑学会大会学術講演梗概集 1993）

16）真鎝恒博，中村位应：作用因子による現象の制御手法の体系化に閴す る研究（日本建学学会計画系論文報告集 1986.2） 